\title{
Molecular taxonomy of Mikrocytos boweri sp. nov. from Olympia oysters Ostrea lurida in British Columbia, Canada
}

\author{
Cathryn L. Abbott*, Gary R. Meyer, Geoff Lowe, Eliah Kim, Stewart C. Johnson \\ Department of Fisheries and Oceans, Pacific Biological Station, 3190 Hammond Bay Road, Nanaimo, BC V9T 6N7, Canada
}

\begin{abstract}
Mikrocytos mackini is a microcell parasite that usually infects Crassostrea gigas distributed along the Pacific Northwest coast of North America. For many years, M. mackini was the only known species in the genus, but there have been multiple recent findings of genetically divergent forms of Mikrocytos in different hosts and in distantly located geographic locations. This note describes $M$. boweri sp. nov. found in Olympia oysters Ostrea lurida collected from and native to British Columbia, Canada, primarily using a molecular taxonomic approach.
\end{abstract}

KEY WORDS: Microcell parasite · Mikrocytosis · Genetic diversity · rDNA • Crassostrea • Mikrocytida Resale or republication not permitted without written consent of the publisher

\section{INTRODUCTION}

Mikrocytos is 1 of 2 genera of microcell parasites that infect oysters; the other is Bonamia. The term microcell was first used by Farley et al. (1988) and reflects that members of both genera are characterized by very small cell sizes $(<5 \mu \mathrm{m})$. Phylogenetically, Bonamia belongs within the Haplosporidia (Carnegie et al. 2000) and Mikrocytos belongs within a newly-described order called Mikrocytida that is sister to haplosporidians (Hartikainen et al. 2014).

The genus Mikrocytos was established by Farley et al. (1988), who described 2 new species in the same publication: M. mackini and M. roughleyi, the latter of which was later reassigned to the genus Bonamia (Cochennec-Laureau et al. 2003). However, Carnegie et al. (2014) found that the identity of the parasite observed histologically as $B$. roughleyi could not be verified by molecular assays and suggested it be regarded as $B$. roughleyi nomen dubium until more information is available. Although M. mackini can infect other species of oysters under experimen- tal conditions (Bower et al. 1997), this parasite is commonly reported only in the Pacific oyster Crassostrea gigas in British Columbia, Canada. Until recently, when M. mackini was discovered infecting Kumamoto oysters C. sikamea in California, USA, the known geographic range of this parasite had been limited to British Columbia and adjacent waters in Washington, USA (Elston et al. 2012, Abbott \& Meyer 2014, this DAO Special). Several recent findings of infections by Mikrocytos sp. (sometimes referred to as 'Mikrocytos-like' organisms), based on their $\sim 10$ to $20 \%$ divergence from $M$. mackini at a short ( $500 \mathrm{bp}$ ) stretch of $18 \mathrm{~S}$ rDNA, have also emerged in Ostrea edulis from Atlantic Canada (Gagné et al. 2008), C. gigas from the UK (named Mikrocytos mimicus; Hartikainen et al. 2014), C. gigas from the Yellow Sea, China (Wang et al. 2010), C. gigas from British Columbia (Abbott et al. 2011), and Donax trunculus clams from France (Garcia et al. 2012). The naming of new Mikrocytos spp. has been hindered by a lack of informative characters and its unresolved phylogeny. However, its evolutionary origins are now 
known (Burki et al. 2013, Hartikainen et al. 2014) and there is sufficient information to begin developing and applying a consistent taxonomic framework for Mikrocytos (Abbott \& Meyer 2014).

In 2011, we PCR-amplified a previously undescribed species of Mikrocytos (Mikrocytos sp.-BC) from Pacific oyster that was genetically divergent from M. mackini (Abbott et al. 2011). Recently, we again detected the same DNA sequence during surveys of the health status of Olympia oysters Ostrea lurida in British Columbia. Abbott \& Meyer (2014) suggest that new species descriptions for Mikrocytos incorporate 18S-rDNA sequence data as well as histopathological and host information. Here we apply these criteria to describe $M$. boweri sp. nov. found infecting Olympia oysters from British Columbia.

\section{MATERIALS AND METHODS}

\section{Oyster sampling and histology}

Forty Ostrea lurida individuals were collected from Swy-A-Lana Lagoon in Nanaimo, British Columbia (BC), Canada, in April 2012 as part of an expansion of a previous study designed to assess the health status of Olympia oysters in BC (Meyer at al. 2010). Each oyster was shucked via the hinge ligament, its shell length was measured, and soft tissues were examined macroscopically for lesions and abnormalities.

For histological examination, 2 transverse cross sections were cut through each oyster (one from the anterior region through the labial palps and another from the mid-body including gills, digestive gland, gut and gonad) and preserved in Davidson's solution (Shaw \& Battle 1957) for 24 to $72 \mathrm{~h}$. For pathogen detection using PCR, small pieces of mantle, labial palps, gills and visceral mass were excised from areas adjacent to the histology cross sections and preserved in 95\% ethanol for subsequent DNA extraction. Histology samples were processed using routine techniques, and tissue sections $(5 \mu \mathrm{m})$ were stained with Harris's modified haematoxylin and $0.5 \%$ alcoholic eosin. The stained histology slides were examined via light microscopy (100 to $1000 \times$ magnification) for the presence of pathogens known to cause disease in bivalve molluscs. Maximum cell diameter measurements of the microcell parasites observed were made using AxioVision 4.6 (Carl Zeiss) digital image processing software.

Upon the discovery that the microcell visualized and sequenced may be novel (described below), a second sampling attempt was made to try to obtain tissue samples suitable for ultrastuctural examination and to learn more about prevalence. An additional 60 Ostrea lurida individuals were collected from the same location on 31 July 2012; methods used were the same as described above, with additional tissue samples preserved in $2.5 \%$ glutaraldehyde.

\section{Molecular methods}

DNA was extracted using a DNeasy Tissue Kit (Qiagen) from 2 Olympia oysters for which histological examination showed infection with a microcell parasite (see 'Results'). To confirm whether Mikrocytos was present, PCR was carried out using the primers Mikrocytos-F/Mikrocytos-R (Carnegie et al. 2003 ) that amplify a short segment of $18 \mathrm{~S}$ rDNA in $M$. mackini and divergent Mikrocytos spp. (Gagné et al. 2008, Wang et al. 2010, Abbott et al. 2011). PCR reactions were $25 \mu \mathrm{l}$ in volume and contained 5 to $50 \mathrm{ng}$ of total DNA, $200 \mu \mathrm{M} d \mathrm{dNT}, 0.2 \mu \mathrm{M}$ of each primer, and $0.5 \times$ Titanum $^{\mathrm{TM}}$ Taq DNA Polymerase (Clontech Laboratories) in 1× Titanium Taq PCR buffer. Thermal cycling conditions were as described for this primer pair by Carnegie et al. (2003).

Following positive results of this first PCR test, bands were sequenced (methods are given below) and DNA sequencing of a longer sequence comprising most of 18S, all of ITS1-5.8S-ITS2 and the $3^{\prime}$ end of 28S rDNA of the Mikrocytos present was pursued. Attempts to amplify this region in 1 fragment (using primers Mm18S_120F and Mm28SR1 from Abbott et al. 2011) were unsuccessful, so we used several primer pairs that generated highly overlapping PCR products such that once sequence reads were assembled, we had high confidence in the consensus sequence. Final contigs of assembled sequences contained fragments generated using the following primer pairs, taken from Abbott et al. (2011) unless otherwise specified, and listed here in the order that the fragments occurred in the $5^{\prime}$ to 3 ' assembly: (1) Mm18S_120F/Mm18S_1403R; (2) Mikrocytos-F/ Mikrocytos-R (Carnegie et al. 2003); (3) Mm18SF1/ 18S-EUK1776-R (this reverse primer is from Carnegie et al. 2003); (4) Mm18S_1128F/pro28S-R; (5) Mm18S_1435F/Mm28SR3; and (6) Mm18S_ 1435F/pro28S-R. Primer sequences and a schematic depiction of annealing locations are given in Abbott et al. (2011).

All PCR reactions were set up as described above using $25 \mu \mathrm{l}$ reaction volumes. The thermal cycling conditions were $3 \mathrm{~min}$ at $95^{\circ} \mathrm{C}$; a 'touchdown' step for 5 cycles of $30 \mathrm{~s}$ at $95^{\circ} \mathrm{C}, 30 \mathrm{~s}$ at 65 to $53^{\circ} \mathrm{C}$ (dropping 
$3^{\circ} \mathrm{C} \mathrm{cycle}^{-1}$ ) and $2.5 \mathrm{~min}$ at $72^{\circ} \mathrm{C}_{i} 30$ cycles of $30 \mathrm{~s}$ at $95^{\circ} \mathrm{C}, 30 \mathrm{~s}$ at $50^{\circ} \mathrm{C}$ and $2.5 \mathrm{~min}$ at $72^{\circ} \mathrm{C}$; and a final cycle of $3 \mathrm{~min}$ at $72^{\circ} \mathrm{C}$. PCR products were visualized on $1.5 \%$ agarose gels stained with SYBR Safe (Invitrogen), and $5 \mu \mathrm{l}$ of each were purified with ExoSAPIT (USB Corporation) for sequencing. Sequencing reactions used Applied Biosystems' BigDye Terminator v3.1 cycle sequencing kit with $1 \mu$ of purified PCR product and $1.6 \mathrm{pmol}$ of primer in a $10 \mu \mathrm{l}$ reaction volume. Sequencing reactions were purified using the Dye EX 2.0 Spin Kit (Qiagen, cat. no. 63183) and run on an ABI 3130xl genetic analyzer.

Sequence data were viewed and edited using Sequencher v5.1 (Gene Codes). Consensus 18S-28S sequences obtained for Mikrocytos from both Olympia oysters tested were aligned with reference sequences from M. mackini (GenBank no. HM56 3060) and Mikrocytos sp.-BC (amplified in Crassostrea gigas from BC by Abbott et al. 2011, GenBank no. HM563061) in BioEdit (Hall 1999) using the Clustal W multiple alignment option with default settings; the alignment was inspected visually. Ends of individual sequences in the alignment were trimmed such that all aligned sequences had the same start and stop point. Pairwise sequence divergence was summarized using percent similarity, which was calculated in BioEdit and represents the number of variable positions divided by the total number of bases sampled. This calculation includes positions where there is a residue in one sequence and a gap in the other, but excludes positions where there is a gap in both sequences being compared.

\section{RESULTS AND DISCUSSION}

\section{Mikrocytos boweri sp. nov.}

Type host: Olympia oyster Ostrea lurida Carpenter, 1864.

Type locality: Swy-A-Lana Lagoon, Nanaimo, British Columbia, Canada $\left(49.1710^{\circ} \mathrm{N}, 123.9375^{\circ} \mathrm{W}\right)$.

Type material: Histological sections of the Olympia oyster Ostrea lurida (no. 8329-26), stained with Harris's modified haematoxylin and $0.5 \%$ alcoholic eosin, have been deposited at the Canadian Museum of Nature, Ottawa ON, Canada (cat. no. CMNPA 2013-0002).

Histological description: Pathology in the visceral mass and gonad consisting of diffuse and focal haemocyte infiltration (Fig. 1A). In both instances, Mikrocytos boweri sp. nov. was observed within vesicular connective tissue cells, often located near the periphery of the host cell and in close proximity to the cell walls (Fig. 1B).

Morphological description: Small, 2-4 $\mu \mathrm{m}$ diameter parasites with a central nucleus and typical 'microcell' morphology. Mean \pm SD size: $2.94 \pm$ $0.41 \mu \mathrm{m}$, range 2.00 to $3.79 \mu \mathrm{m}(\mathrm{n}=16)$. Description and measurements based on light microscopy of histological sections (ultrastructural examination is not available).

Prevalence of infection: Detected by histology in $5 \%$ (2 of 40$)$ of specimens collected in spring (April) and in $0 \%$ (0 of 60 ) specimens collected in July.

Intensity of infection: No gross signs of disease were observed. Diffuse and focal haemocyte infiltra-

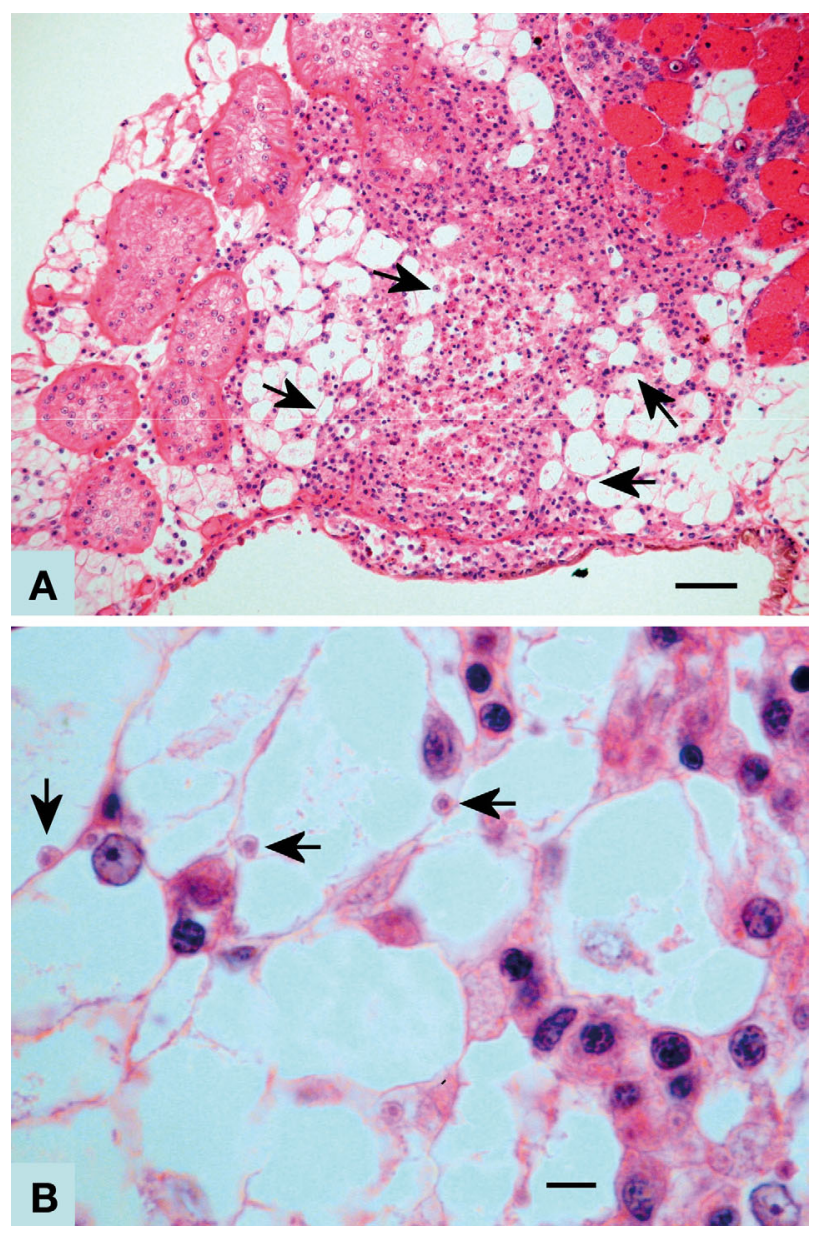

Fig. 1. Ostrea lurida infected by Mikrocytos boweri sp. nov. Histological tissue sections stained with haematoxylin and eosin. (A) Low magnification showing small foci of haemocyte infiltration (lesion) located in the vesicular connective tissue between the kidney and gonad (scale bar $=50 \mu \mathrm{m}$ ). (B) High magnification showing $M$. boweri sp. nov. parasites (arrows) within the vesicular connective tissue cells and in close proximity to the cell walls (scale bar $=5 \mu \mathrm{m}$ ) 
tion (Fig. 1A) observed by histology was consistent with light intensity infections of intracellular Mikrocytos parasites (<50 Mikrocytos boweri sp. nov. detected per tissue section).

Etymology: The specific epithet derives from shellfish parasitologist Dr. Susan Bower, who led the advancement of scientific knowledge of Mikrocytos mackini from its initial description by Farley et al. (1988) until her retirement in 2007.

Molecular taxonomy: We obtained 2 DNA sequences covering partial 18S, complete ITS1-5.8SITS2 and the 3' end of 28S of Mikrocytos boweri sp. nov. These 2 sequences were obtained from 2 different host animals. Although the $M$. boweri sp. nov. sequence was not identical between the 2 host animals, there was no parasite sequence variation observed within each host individual, so sequence reads obtained using direct sequencing were consistently clean and unambiguous. After trimming, the length of the DNA sequence obtained from Olympia oyster no. 8329-26 was 1984 bp (GenBank no. KF297352) and from Olympia oyster no. 8329-05 was 1818 bp (GenBank no. KF297353). We selected $M$. boweri sp. nov. from oyster no. 8329-26 as the type material because slightly more sequence at the $5^{\prime}$ end of the partial 18S was obtained from this sample due to differences in sequencing success. Information on sequence length variation between the $2 M$. boweri sp. nov. sequences that is due to true genetic differences rather than differences in sequencing success is captured immediately below in the description of the sequence alignments.

When the 2 Mikrocytos boweri sp. nov. sequences from Olympia oysters were aligned with Mikrocytos sp.-BC (1903 bp, GenBank no. HM563061; Abbott et al. 2011), the 3 sequences were found to be virtually identical genetically outside of ITS1. With ITS1 excluded, the alignment was 1763 bp long with only 1 variable site between $M$. boweri sp. nov. and Mikrocytos sp.-BC (Table 1), hence the latter is presumed to be $M$. boweri sp. nov. The ITS1 region was AT rich and highly repetitive. The 3 comparisons of pairwise sequence similarity within $M$. boweri sp. nov. ranged from 69.1 to $83.2 \%$ (Table 1), with most of the variation due to insertion/deletion mutations rather than substitutional changes. When gapped sites in ITS1 were removed, pairwise comparisons of $M$. boweri sp. nov. sequences showed $>93 \%$ similarity in this region.

These sequences were then aligned with the reference sequence for Mikrocytos mackini (2120 bp, GenBank no. HM563060), which resulted in a final alignment that was $1924 \mathrm{bp}$ long including 160 posi- tions that contained a gap. The first base of this alignment corresponded to base pair 251 of the M. mackini reference sequence. The various regions within the rDNA cistron were delineated based on the annotation by Abbott et al. (2011), such that the end of 18S, complete ITS1, complete $5.8 \mathrm{~S}$ and the start of ITS2 were all identified but the junction between ITS2 and 28S was not. Lengths of the whole alignment and various sections therein as well as pairwise sequence divergence estimates based on percent similarity are presented in Table 1. Alignment confidence based on visual inspection was high except for in ITS1 (161 bp). With ITS1 excluded, sequence similarities between $M$. mackini and $M$. boweri sp. nov. (considered here as including 'Mikrocytos sp.-BC') were generally much lower than values observed within $M$. boweri sp. nov., ranging from $65.7 \%$ in ITS2/28S to $97.5 \%$ in 5.8S (Table 1). Over $1265 \mathrm{bp}$ of the $18 \mathrm{~S}$ region, $M$. mackini and $M$. boweri sp. nov. (including 'Mikrocytos sp.-BC') were 9\% divergent, which suggests they are indeed different species.

Comments: 18S sequences have been used extensively to help delineate species boundaries in protistan groups with few or highly-conserved morphological features (Caron et al. 2009 and references therein). In analyses involving ca. 2500 pairwise comparisons of complete $18 \mathrm{~S}$ sequences from a taxonomically broad range of morphologically-defined protistan species, Caron et al. (2009) determined that sequence similarity between species within a genus averaged $87 \%$, while intra-specific sequence similarity averaged 98\%. That Mikrocytos mackini and $M$. boweri sp. nov. are only $91 \%$ identical at 1265 aligned bp of $18 \mathrm{~S}$ and have much higher levels of divergence at faster-evolving ITS rDNA regions provides strong support for their separate species status.

The mean shell length of the Olympia oysters examined was $33.9 \pm 7.3(\mathrm{SD}) \mathrm{mm}$, and no lesions or abnormalities in the soft tissues of necropsied oysters were observed. Mikrocytos boweri sp. nov. was found near the periphery of host cells and in close proximity to the cell walls. This distribution is similar to what was observed for the Mikrocytos-like parasite reported infecting Ostrea edulis from the Atlantic Ocean (Gagné et al. 2008).

To our knowledge, this is the first report of Mikrocytos infections in wild Olympia oysters from BC. During previous health assessment surveys of this species in this region using both microscopic and molecular methods, infections with Mikrocytos sp. were not detected (Meyer et al. 2010). Similarly, when we conducted additional sampling in mid-summer 
Table 1. Pairwise percent identity estimates for rDNA sequences from Mikrocytos mackini, 'Mikrocytos sp.-BC' from Abbott et al. (2011) (shortened to $M$. sp-BC in the table and considered here as conspecific with $M$. boweri sp. nov.) and 2 samples (nos. 8329-05 and 8329-26) of $M$. boweri sp. nov. found in this study infecting Olympia oysters. Estimates are provided for the whole alignment; the whole alignment except ITS1 (161 bp excluded) due to poor alignment within the ITS1; and for each discernible rDNA region separately

\begin{tabular}{|c|c|c|c|c|}
\hline & & M. mackini & M. sp-BC & $\begin{array}{c}\text { M. boweri sp. nov. } \\
(8329-05)\end{array}$ \\
\hline Whole alignment $^{\mathrm{a}}$ (1924 bp) & $\begin{array}{l}\text { M. mackini } \\
\text { M. sp-BC } \\
\text { M. boweri sp. nov. (8329-05) } \\
\text { M. boweri sp. nov. (8329-26) }\end{array}$ & $\begin{array}{l}- \\
81.9 \\
83.8 \\
83.3\end{array}$ & $\begin{array}{l}- \\
97.3 \\
97.7\end{array}$ & $\overline{98.7}$ \\
\hline Excluding ITS1 only (1763 bp) & $\begin{array}{l}\text { M. mackini } \\
\text { M. sp-BC } \\
\text { M. boweri sp. nov. (8329-05) } \\
\text { M. boweri sp. nov. (8329-26) }\end{array}$ & $\begin{array}{l}- \\
86.2 \\
86.2 \\
86.2\end{array}$ & $\begin{array}{c}- \\
99.9 \\
100.0\end{array}$ & $\overline{99.9}$ \\
\hline 18S (1265 bp) & $\begin{array}{l}\text { M. mackini } \\
\text { M. sp-BC } \\
\text { M. boweri sp. nov. (8329-05) } \\
\text { M. boweri sp. nov. (8329-26) }\end{array}$ & $\begin{array}{l}- \\
91.2 \\
91.2 \\
91.2\end{array}$ & $\begin{array}{l}- \\
100 \\
100\end{array}$ & $\overline{100}$ \\
\hline $\operatorname{ITS}^{\mathrm{a}}(161 \mathrm{bp})$ & $\begin{array}{l}\text { M. mackini } \\
\text { M. sp-BC } \\
\text { M. boweri sp. nov. (8329-05) } \\
\text { M. boweri sp. nov. (8329-26) }\end{array}$ & $\begin{array}{l}- \\
35.4 \\
47.8 \\
42.8\end{array}$ & $\begin{array}{l}- \\
69.1 \\
73.7\end{array}$ & $\overline{83.2}$ \\
\hline 5.8S (121 bp) & $\begin{array}{l}\text { M. mackini } \\
\text { M. sp-BC } \\
\text { M. boweri sp. nov. (8329-05) } \\
\text { M. boweri sp. nov. (8329-26) }\end{array}$ & $\begin{array}{r}- \\
97.5 \\
97.5 \\
97.5\end{array}$ & $\begin{array}{l}- \\
100 \\
100\end{array}$ & - \\
\hline ITS2-28S (377 bp) & $\begin{array}{l}\text { M. mackini } \\
\text { M. sp-BC } \\
\text { M. boweri sp. nov. (8329-05) } \\
\text { M. boweri sp. nov. (8329-26) }\end{array}$ & $\begin{array}{l}- \\
65.7 \\
65.7 \\
65.7\end{array}$ & $\begin{array}{c}- \\
99.7 \\
100\end{array}$ & $\overline{99.7}$ \\
\hline
\end{tabular}

(July) after discovering Mikrocytos boweri sp. nov. in spring (April), all 60 specimens examined were negative for Mikrocytos. The only other relevant report from this region is by Bower et al. (1997), who found that Olympia oysters (then called Ostrea conchaphila) became infected with $M$. mackini after a field challenge and subsequent laboratory incubation in cool water $\left(10^{\circ} \mathrm{C}\right)$.

Two other studies have reported unconfirmed findings of Mikrocytos in Olympia oysters. Farley et al. (1988) found microcell infections in vesicular connective tissue cells in samples collected from Yaquina Bay, Oregon (USA), between 1969 and 1971. This may very well have been Mikrocytos, which most visibly infects vesicular connective tissue, whereas Bonamia more typically infects host haemocytes (Carnegie \& Cochennec-Laureau 2004). Friedman et al. (2005) reported rare occurrences of a Mikrocytoslike protist in Olympia oysters from San Francisco Bay, California (USA), that were morphologically consistent with $M$. mackini infection; however, $M$. mackini-specific fluorescent in situ hybridization assays yielded negative results.

The current discovery of Mikrocytos boweri sp. nov. infecting Olympia oysters in BC is the first time a Mikrocytos parasite has been definitively identified in a species of oyster that is native to North America. All previous confirmed findings of Mikrocytos on the Pacific coast of North America have been cases of $M$. mackini infecting the introduced oyster species Crassostrea gigas and C. sikamea. The microcell parasite in C. sikamea was determined to be M. mackini based on $\sim 700 \mathrm{bp}$ of rDNA sequence (including all of ITS1-5.8S-ITS2) being identical to of all $71 \mathrm{M}$. mackini samples sequenced from its traditionally-known geographic range in $\mathrm{BC}$ and Washington (Elston et. al 2012). Available evidence, including data presented here, suggest that this ITS region is highly variable in Mikrocytos and may regularly show within-species levels of variation, which could prove useful in the future for strain-level discrimination and for verifying close taxonomic relationships (Abbott \& Meyer 2014). 
Acknowledgements. We thank T. Norgard for sample collection and S. R. Gilmore for helpful feedback on the draft manuscript.

\section{LITERATURE CITED}

Abbott CL, Meyer GR (2014) Review of Mikrocytos microcell parasites at the dawn of a new age of scientific discovery. Dis Aquat Org 110:25-32

Abbott CL, Gilmore SR, Lowe G, Meyer G, Bower S (2011) Sequence homogeneity of internal transcribed spacer rDNA in Mikrocytos mackini and detection of Mikrocytos sp. in a new location. Dis Aquat Org 93:243-250

Bower SM, Hervio D, Meyer GR (1997) Infectivity of Mikrocytos mackini, the causative agent of Denman Island disease in Pacific oysters Crassostrea gigas, to various species of oysters. Dis Aquat Org 29:111-116

Burki F, Abbott CL, Meyer GR, Sierra R, Corradi N, Pawlowski J, Keeling PJ (2013) Phylogenomics of the intracellular parasite Mikrocytos mackini reveals evidence for a mitosome in Rhizaria. Curr Biol 23:1541-1547

Carnegie RB, Barber BJ, Culloty SC, Figueras AJ, Distel DL (2000) Development of a PCR assay for detection of the oyster pathogen Bonamia ostreae and support for its inclusion in the Haplosporidia. Dis Aquat Org 42: 199-206

> Carnegie RB, Cochennec-Laureau N (2004) Microcell parasites of oysters: recent insights and future trends. Aquat Living Resour 17:519-528

> Carnegie RB, Meyer GR, Blackbourn J, Cochennec-Laureau N, Berthe FCJ, Bower SM (2003) Molecular detection of the oyster parasite Mikrocytos mackini, and a preliminary phylogenetic analysis. Dis Aquat Org 54: 219-227

> Carnegie RB, Hill KM, Stokes NA, Burreson EM (2014) The haplosporidian Bonamia exitiosa is present in Australia, but the identity of the parasite described as Bonamia (formerly Mikrocytos) roughleyi is uncertain. J Invertebr Pathol 115:33-40

Caron DA, Countway PD, Savai P, Gast RJ and others (2009) Defining DNA-based operational taxonomic units for microbial-eukaryote ecology. Appl Environ Microbiol 75: 5797-5808

Editorial responsibility: Ryan Carnegie, Gloucester Point, Virginia, USA
Cochennec-Laureau N, Reece KS, Berthe FCJ, Hine PM (2003) Mikrocytos roughleyi taxonomic affiliation leads to the genus Bonamia (Haplosporidia). Dis Aquat Org 54: 209-217

> Elston RA, Moore J, Abbott CL (2012) Denman Island disease (causative agent Mikrocytos mackini) in a new host, Kumamoto oysters Crassostrea sikamea. Dis Aquat Org 102:65-71

Farley AC, Wolf PW, Elston RA (1988) A long-term study of 'microcell' disease in oysters with a description of a new genus, Mikrocytos (g. n.), and two new species, Mikrocytos mackini (sp. n.) and Mikrocytos roughleyi (sp. n.). Fish Bull 86:581-593

Friedman CS, Brown HM, Ewing TW, Griffin FJ, Cherr GN (2005) Pilot study of the Olympia oyster Ostrea conchaphila in the San Francisco Bay estuary: description and distribution of diseases. Dis Aquat Org 65:1-8

> Gagné N, Cochennec N, Stephenson M, McGladdery S, Meyer GR, Bower SM (2008) First report of a Mikrocytoslike parasite in European oysters Ostrea edulis from Canada after transport and quarantine in France. Dis Aquat Org 80:27-35

Garcia C, Arzul I, Joly JP, Guichard B and others (2012) Mikrocytos like protozoans and the shellfish Donax trunculus mortality events in France. J Shellfish Res 31:273

Hartikainen H, Stentiford GD, Bateman KS, Berney C and others (2014) Mikrocytids are a broadly distributed and divergent radiation of parasites in aquatic invertebrates. Curr Biol 24:807-812

Hall TA (1999) BioEdit: a user-friendly biological sequence alignment editor and analysis program for Windows 95/98/NT. Nucleic Acids Symp Ser 41:95-98

> Meyer GR, Lowe GJ, Kim E, Abbott CL, Johnson SJ, Gilmore SR (2010) Health status of Olympia oysters (Ostrea lurida) in British Columbia, Canada. J Shellfish Res 29:181-185

Shaw BL, Battle HI (1957) The gross and microscopic anatomy of the digestive tract of the oyster Crassostrea virginica (Gmelin). Can J Zool 35:325-347

Wang ZW, Liang YB, Lu X (2010) Use of histopathology, PCR and in situ hybridization methods to detect the parasite Mikrocytos sp in Pacific oyster Crassostrea gigas from the northern coast of the Yellow Sea, China. Aquat Living Resour 23:125-130

Submitted: March 18, 2013; Accepted: November 22, 2013 Proofs received from author(s): July 10, 2014 